\title{
Members’ Behavior Towards Baitul Mal Wa Tamwil
}

\section{Elis Mediawati, Arim Nasim, Silviana Agustami, Wina Sholehah, Andi Irwansyah Mattupuang, Siska Yulia Solihati, and Tsara Azizah}

Accounting Department, Universitas Pendidikan Indonesia, Indonesia

\section{Abstract}

This study aims to analyze the criteria considered by individual members in choosing Baitul Mal Wa Tamwil (BMT) and analyzing the attitudes of members towards BMT. Research subjects are individual members who use BMT services. Data analysis method is descriptive statistics. The results of the analysis concluded that there were 5 factors that were considered by the members in choosing BMT, among others: ease of obtaining business capital financing, usury-free, security, satisfying service and close to home. Religious factors are not the main reason for individual members in choosing BMT. Members consider more economic factors, namely the ease of obtaining business capital.

Received: 10 February 2019

Accepted: 14 March 2019

Published: 28 March 2019

Publishing services provided by Knowledge E

(c) Elis Mediawati et al. This article is distributed under the terms of the Creative Commons

Attribution License, which permits unrestricted use and redistribution provided that the original author and source are credited.

Selection and Peer-review under the responsibility of the ICIEBP Conference Committee.

\section{G OPEN ACCESS}

Keywords: behavior, members, BMT, financing, usury

\section{Introduction}

BMT is a business organization that also play a social function and role of the BMT as follows: As an investment manager, to play its role as an agent or as a liaison for the owners of the funds; As an investor, if the source of the funds obtained from members or loans from other parties are then managed in professional and effective without the special requirements of the owner of the fund; Social function, providing better social services to members and dhua'fa (Mediawati and Agustami 2016).

In addition to sharia principles that are the basis of its fundamentals, the superiority of BMT in operational terms is carried out by providing assistance to its members so that this approach model raises a very high level of trust to members. This is why BMT is booming as a financial institution. Several studies have been carried out regarding people's preference for Islamic financial institutions. Research on community behavior has been carried out in Islamic banks. The results of research in Islamic banks regarding the preferences of customers to save in Islamic banks are driven by economic and religious factors. 
Research using a questionnaire to determine the attitudes, behavior and selection criteria of banks, both Islamic and conventional banks in Jordan found that fast and efficient service, bank reputation and image, and bank credibility are the main factors in choosing banks, both Islamic and conventional banks ( Erol and El-Bdour R. 1989). Other studies have found that fast and efficient services have the highest value among other selection criteria. Similar results were also found from studies conducted by (Worthington,2008; Haron et al, 1994; Gerrard and Cunningham,1997). That shows that religious factors are not the main reason for consumers in choosing a bank. Other studies found that most respondents chose religion as the main factor motivating them to use sharia banking products and services (Worthington, 2008; Metawa et al, 2008; Al-Sultan, 2016: Bley and Kuehn, 2003).

BMT has considerable development potential. But how big the potential is, which market segmentation has good potential, what products are expected by the community and what factors influence the decision making to choose a financial institution and how its behavior needs to be studied further. This is important to determine the development strategy and scale of its development in the future so that it can help in developing BMT empowerment programs in increasing the independence of the community in doing business according to Islamic sharia and improving the welfare of society in general. This research is designed to provide answers to these questions

\section{Research Method}

This research is a type of survey research on the behavior of members towards BMT. The population of this study was all members of BMT in Bandung. The technique used in determining the sample is the accidental sampling method. Data collection methods in this study are questionnaires, namely by using a list of questions that have been prepared to be filled in by the respondents selected as samples. Data analysis method is descriptive statistics.

\subsection{The result}

Baitul Mal Wat Tamwil (BMT) is a microfinance institution oriented to developing micro business according to Islamic sharia and conducting social activities by utilizing the people's funds in the form of zakat, infaq and waqf for the development of mustahiq productive businesses in order to improve the welfare of members and society in generally. Members are important stakeholders and have an important role in BMT 
governance. Members are owners and users of BMT services. The participation and awareness of members towards BMT is very necessary in conducting business efficiently and in accordance with sharia principles. Members can use market discipline to improve BMT governance by attracting deposits from poor performing BMTs. To do this, members must understand the nature of BMT, information about management and BMT performance.

Characteristics of respondents were $54.78 \%$ of women and $45.22 \%$ of men. Age, education level and occupation of respondents can be described as follows:
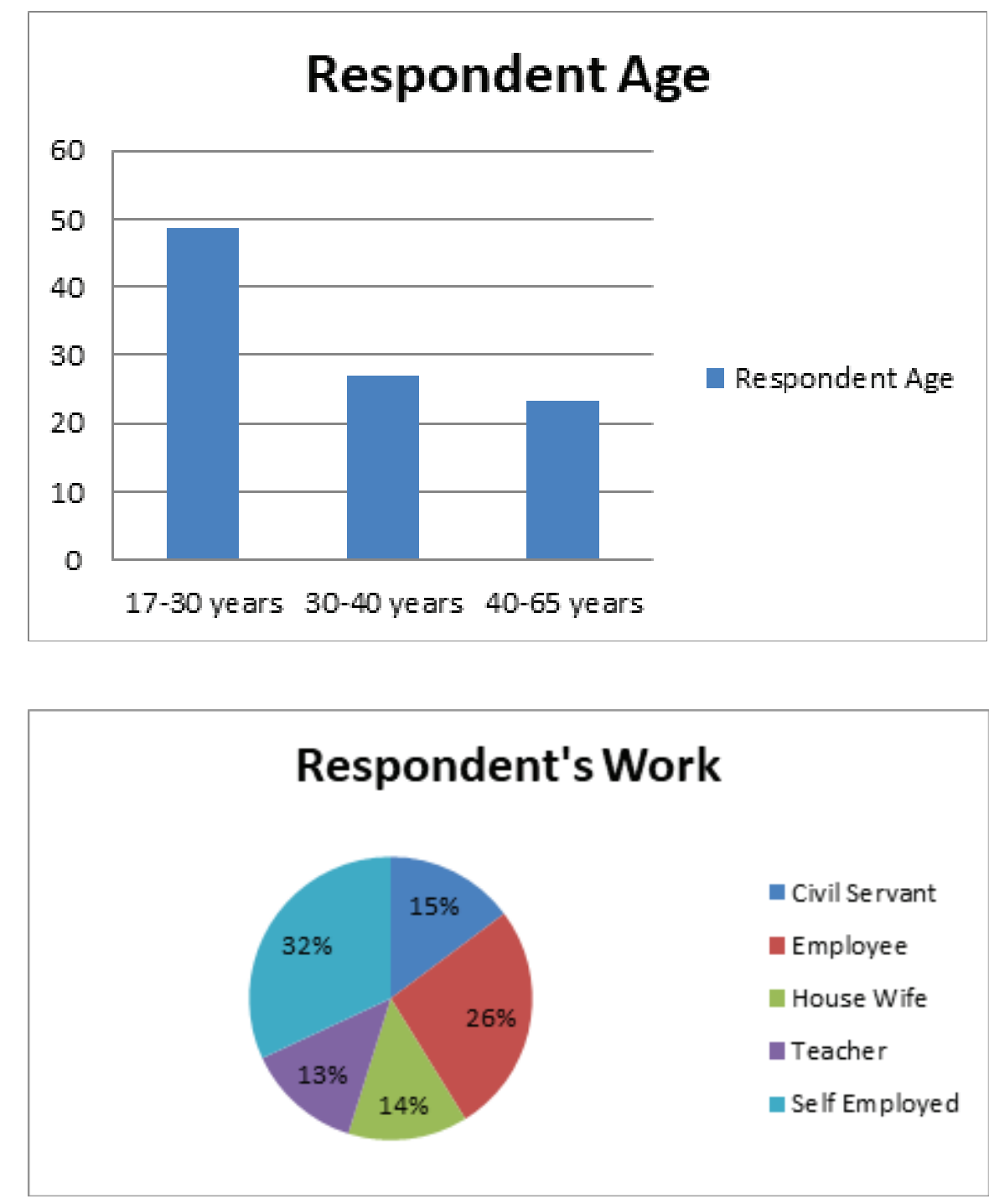

The reason they chose to become a member of BMT was a security reason, to get ease in obtaining financing for venture capital, because it was free of usury, satisfying service and other reasons such as close comfort from the house. Which can be described as follows: 


\section{The reason for being a member of BMT}

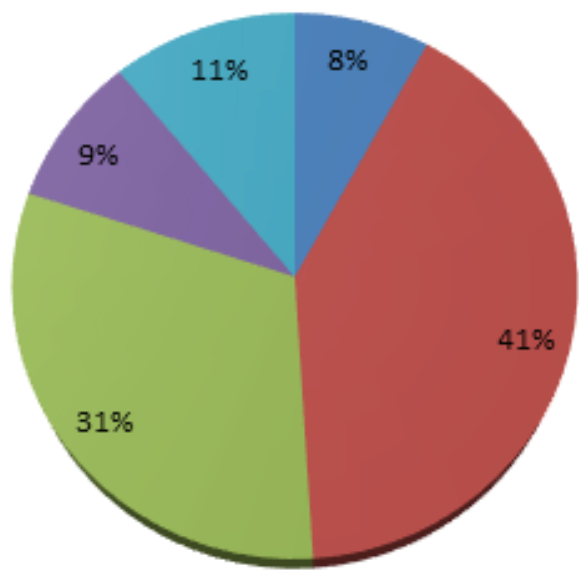

- Security

- The Ease of getting a home financing business capital

wree of usury

- satisfying service

close to home

One important aspect of disclosing member account information as a depositary is information sharing. Respondents answered yes at $60.87 \%$ and not $39.13 \%$ when asked whether you got information on the results of savings.

Members' reaction if BMT does not provide ease of procedure in financing transactions, then $89 \%$ they will look for other BMTs, which provide more convenience in financing business capital and the rest will survive in the BMT.

As a sharia institution operating in accordance with sharia principles, there is a Sharia Supervisory Board (SSB), and 79.13\% of respondents know the existence of SSB in BMT, and the remaining $20.87 \%$ are not aware of the existence of SSB in BMT.

The survey results on several questions that have important implications for BMT governance show the role of members in improving BMT governance through market discipline. If BMT fails to perform well and does not perform their duties, members will respond by leaving as members and withdrawing funds. This is seen in the results reported in the table below. When asked whether members who have savings will move their funds to other institutions if their BMT provides a lower profit sharing rate than other institutions for several years, $61.73 \%$ indicate that they will move funds to other institutions whose returns are higher, $38.30 \%$ will continue to save at the BMT.

However, if it is lower than a year, members tend to prefer to keep saving at the BMT as much as $78.26 \%$ and $21.74 \%$ will move their funds to other institutions with higher returns. The data shows that members will withdraw their funds to other institutions that have a significantly higher return when BMT provides a lower profit sharing rate than other institutions for several years. 

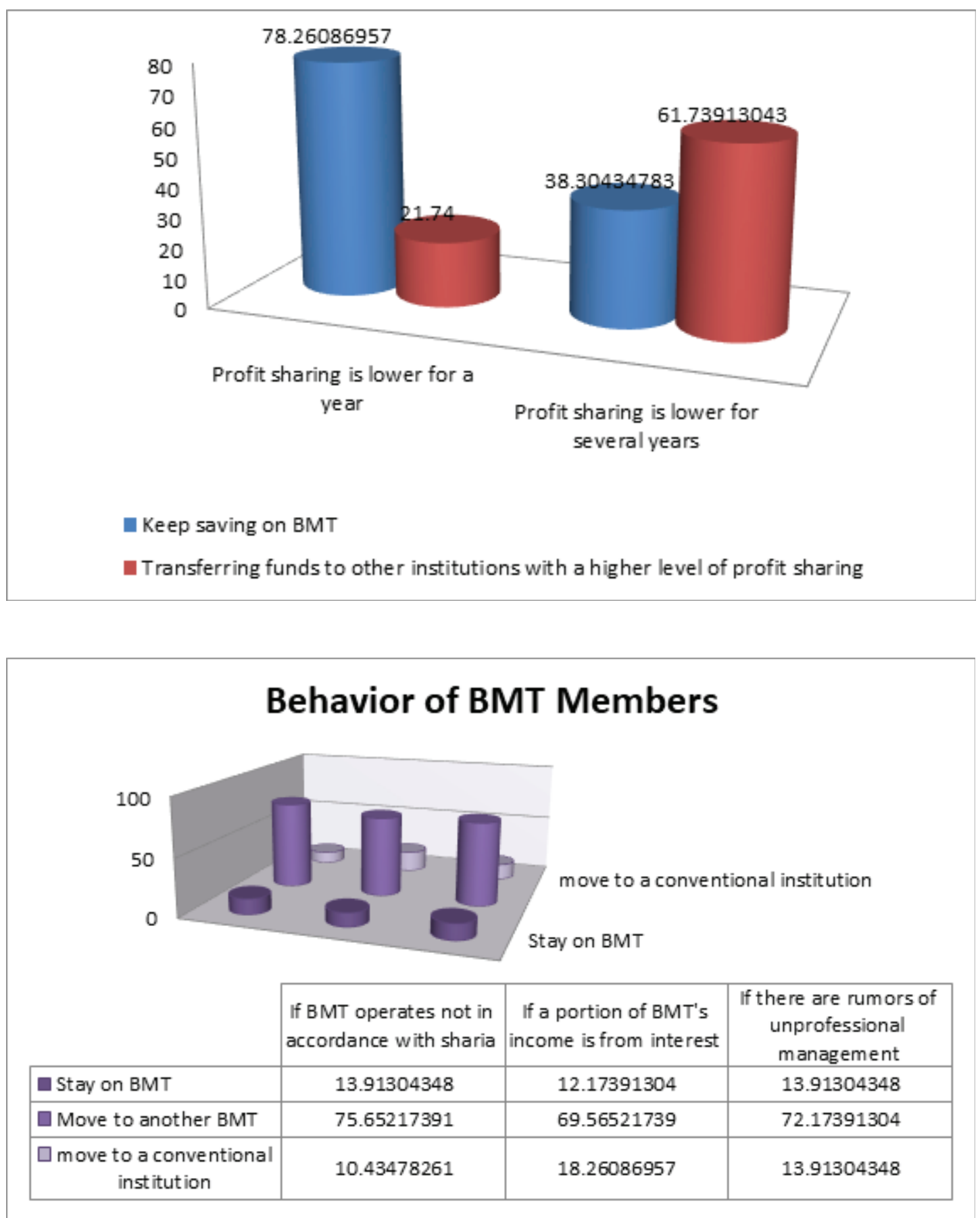

The table above shows that members who have savings will punish BMT by withdrawing funds if there are rumors about the poor performance of the bank, only $13.91 \%$ of depositors who will not move to another bank. $72.17 \%$ of depositors will move to other BMTs with better management; the remaining $13.91 \%$ will move to conventional institutions with professional management. These results indicate that if BMT does not conduct management professionally and does not provide a good rate of return, it will risk losing depositors. 
The survey reports depositors' reactions that are possible if BMT fails to perform tasks related to conducting business in accordance with sharia. If the depositor knows that BMT is not doing business in accordance with sharia principles, then most of them (87.09\%) will transfer their funds to other BMT, which is $75.65 \%$ will transfer their funds to the more sharia-compliant BMT and $10.43 \%$ will move funds to conventional institutions. Only a small percentage of those who will remain on the BMT are $13.91 \%$.

Similar results appear in depositors' responses when asked about their reactions if they find out that part of BMT's income is from interest. If the case arises, then $88 \%$ of them will transfer their funds to another BMT, which is $69.56 \%$ will move their funds to another BMT and $18.26 \%$ will move their funds to conventional institutions with higher returns, the remaining $12.17 \%$ will survive in the BMT

\section{Conclusions}

Based on the results of the analysis and interpretation of the results of research on the behavior of members towards BMT, it can be concluded that members have a reason to choose to become BMT members because of economic factors, namely getting ease in financing venture capital and reasons for religious factors that are free of usury. The reason was supported by their statement when responding to BMT that did not provide easy financing for business capital and in its activities were not in accordance with sharia then they would respond by leaving the BMT.

\section{References}

[1] Al-sultan, Waleed. 2016. "Financial Characteristics of Interest-Free Banks and Conventional Banks."

[2] Bley, Jorg, and Kermit Kuehn. 2003. "CONVENTIONAL VERSUS ISLAMIC FINANCE区: STUDENT KNOWLEDGE AND PERCEPTION." 5(4).

[3] Erol, C, and El-Bdour R. 1989. "Attitudes, Behaviour and Patronage Factors of Bank Customers Towards Islamic Banks." International Journal of Bank Marketing.

[4] Gerrard, Philip, and J Barton Cunningham. 1997. "Islamic Banking: A Study in Singapore."

[5] Al-sultan, Waleed. 2016. "Financial Characteristics of Interest-Free Banks and Conventional Banks."

[6] Bley, Jorg, and Kermit Kuehn. 2003. "CONVENTIONAL VERSUS ISLAMIC FINANCE: STUDENT KNOWLEDGE AND PERCEPTION." 5(4). 
[7] Erol, C, and El-Bdour R. 1989. "Attitudes, Behaviour and Patronage Factors of Bank Customers Towards Islamic Banks." International Journal of Bank Marketing.

[8] Gerrard, Philip, and J Barton Cunningham. 1997. "Islamic Banking: A Study in Singapore."

[9] Haron, S, Ahmad N, and Planisek S. "Bank Patronage Factors of Muslim and Non Muslim Customers." International Journal of Bank Marketing.

[10] Mediawati, Elis, and Silviana Agustami. 2016. "Sharia Compliance on Murabaha Financing." 15: 161-62.

[11] Metawa, Saad A, Mohammed Almossawi, Saad A Metawa, and Mohammed Almossawi. 2008. "Banking Behavior of Islamic Bank Customers $\bigotimes$ : Perspectives and Implications."

[12] Worthington, Andrew. 2008. "An Empirical Survey of Individual Consumer, Business Firm and Financial Institution Attitudes towards Islamic Methods of Finance." 35(11): 783-808. 